\title{
Critical Discourse Analysis of Imran Khan Dharna Speeches in Socio-Political
}

\author{
Perspective \\ * Aasia Nusrat, Assistant Professor \\ ** Dr. Sardaraz Khan, Director ORIC \\ *** Ms. Shaista Shehzadi, Lecturer
}

\begin{abstract}
This study aims to explore and uncover power play in Dharna 2014 speeches of Imran Khan. The study has followed the theoretical perspective of power (Fairclough, 2003) in its two-dimensions i.e. power within and behind discourse. This research is significant in terms of enabling common public of Pakistan to understand their leader in terms of the concept of power by comprehending the meaning that language conveys. The research method applies thematic analysis and utilizes Fairclough's three-dimensional model (1989) as data analyzing tool. The speeches were analyzed by considering Textual, Discursive and Societal levels of discourse. The key findings in case of power within discourse include that the speaker showed the use of pronoun ' $I$ ' in order to show his power and by using the pronoun 'we' he gained the support of the audience in order to win their hearts and reflect this as a power on the rulers. The speakers explained in detail the unjust rule of the government by using different linguistic tools like modal verbs, vocabulary, transitivity, interdiscourse etc. Moreover, in case of power behind discourse, the key findings include the power of west and Islam in the speaker's speeches.
\end{abstract}

Keywords: Critical discourse analysis, dharna speeches, power within discourse, political discourse. Introduction

In public discourse, limited members of society have access to the public to convey their beliefs, and ideas. According to van Dijk (1997), one of the most important resources is the public discourse that is shared by representatives of elites, for instance, politicians, writers, intellectuals, etc. either through text or talk to influence public in the forms of parliamentary discussions, news stories, articles, TV shows, advertisements, and so on. Public discourse is used as a tool for the social reproduction of power (van Dijk, 1997) that helps politicians not only to exert their political power but reproduce political power through public discourse. Political discourse is the major source of shaping opinion of general public in public discourse. Fairclough (2001) holds that only those who have the ability to shape the public opinion can approach the power structures. The language used in a political discourse has specific features that reflect the ideological position of politicians through which the readers' ideological position is generated. Political speech, parliamentary debates, media interviews and shows, and political advertising are some of the features of political discourse (van Dijk, 1997).

Political speech, being a political genre, more often is used to perform politics. It can also be used as an object of the analysis to see the hidden agenda behind the statements of the speakers since language in political speech can control and influence political action and trust of the audience (van Dijk, 1997). Political speech is one type of discourse which produces and reproduces beliefs, opinions, and ideologies (Wodak, 2004). In other words, political speech must have certain ideology to be spread among the audience.

Political discourse is not only concerned with the political text structure but also with the political context as Van Dijik holds, "there is a need for cognitive collaboration between situations and talk is text that is a context." (Dijik, 2006: p.733). Hence, being a Prime Minister, a party leader is a party worker with a relevant context in his political discourse that is perceived by people.

\footnotetext{
* Department of Humanities, COMSATS University Islamabad, Lahore Campus, Pakistan

Email: aasianusrat@ cuilahore.edu.pk

** University of Science and Technology Bannu

Email: sardarazsorani@gmail.com

*** Department of English Language and Literature, University of Lahore, Pakistan

Email: shahzadi.shaista@yahoo.com
} 
Furthermore, politics is mainly concerned with power either to make decisions, to undermine value of competitors or control people's behavior and minds in order to control ideologies and people's beliefs to win the race of Power. According to Bayram (2010), it is a struggle for power in command to put some administrative, financial and societal ideas into exercise. In this course, language plays a vital role for every political act that is prepared, attended and frolicked by language. It is the most important and dynamic tool that representatives use in order to form the political views of the voters with the goal of marketing their thoughts to them. Chimbarange, Takavarasha and Kombe (2013) are of the opinion that the key purpose of politicians is to encourage their spectators about the rationality of their political rights. They suggest that representatives take pains to prove to the electorates to change their political philosophies and hold on to theirs.

Hence, this study investigates language as an effective source of power. Thus, it rises from the requirement to critically analyze the language used in the political speeches of Imran Khan's dharna in 2014. Imran Khan is a renowned former cricketer and head of Pakistan Tehreek-e-Insaf (PTI), one of the most successful political parties in Pakistan.

This paper shows how language creates and sustains power relations and conceptual constructions of society within the framework of Critical Discourse Analysis (CDA). Imran Khan emerged as one of the most popular leader after the election of 2013, and he was also the leader of opposition, on the other hand. He motivated the audience through the use of language and persuaded them to be ready against the party ruling at that time. Hence, it would be significant to know the use of power through political discourse in the form of Imran Khan's speech he has delivered in his Dharna in 2014. The main objectives of this study is to find out:

a) How power is displayed and practiced at textual level of Imran Khan Dharna speech in terms of development of cohesion; Grammar (Transitivity; Modality), lexical items and pronoun?

b) How power is displayed and practiced at discursive level of Imran Khan Dharna speech in terms of interdiscursivity and intertextuality?

c) How does display of the power is represented at societal level of Imran Khan Dharna speech in terms of order of discourse?

\section{Literature Review}

\section{Critical Discourse Analysis (CDA)}

In order to study how language exercises its power in a society, critical discourse analysis is carried out. CDA mainly deals with discourse and the people of the society. We have to know about the identification of people and how they act, think and speak (Taiwo, 2007). CDA refers to the ways of understanding the social world drawn by critical theory. Dijik (2009) describes that CDA reveals how the discursive sources are maintained and reproduced within social, political and historical context. Furthermore, ' $\mathrm{C}$ ' in CDA stands for the critical study of hidden connections and causes between language, power and ideology. It is the explanation of the ways in which unequal power relations are produced and naturalized in the discourse. However, the link between discourse and society is not directly proportional, rather, it depends on the cognitive process. People use their cognitive abilities to analyze discourse and it is because of it the people can produce discourse (Gadavani, 2002).

As the term suggests, Critical Discourse Analysis is the analysis of discourse in a critical way. According to Richardson (1987), the word critical is important because to read innocently, nonanalytically, is to be manipulated and mystified. Being critical is not always synonymous with being negative. According to Kendall (2007), the term critical means that -through the procedures, creating dense arrangements of power relations and ideology manifest. Van Dijik (2001) summarized the aims of CDA as follows:

a) CDA points out issues related to society and politics.

b) It analyzes discourse in the form of power.

c) $\mathrm{CDA}$ and DA interpret discourse differently.

d) CDA tells us how discourse structure affects the society. research.

That is why in the current study, CDA's framework is used to analyze the speeches in this

\section{Fairclough 3D Model}

Fairclough (1989) presented a three-dimensional model of CDA in his work "Language and Power". This model is supposed to be an interdisciplinary approach to the study of discourse, for it views 'language as a form of social practice' (Fairclough, 1989 p. 20) and focuses on the ways through 
which social and political dominance is exercised in discourse by 'text and talk'. Moreover, the threedimensional model highlights processes of the production and reception of a 'discourse fragment' in a particular context. Fairclough (1989) identifies three dimensions to critical discourse analysis. The first dimension represents the discourse fragment, a "Text" that could be any object of analysis, including verbal, visual or verbal and visual texts. The second dimension of 'discursive practices' can be described in terms of production and reception of a 'text' in a particular 'context'. The context is 'situational as well as intertextual'. Situational context deals with the time and place of text production, whereas intertextual context is related to the producers and receivers of the discourse. The third dimension of discourse could be described as 'power behind discourse' or as 'social practices' functioning behind the entire process and governing the power relations in discourse.

Al-Haq and Al-Sleibi (2015) analyzed three speeches of Iranian Prime minister to find out relationship between discourse and power. At the first level, the three speeches were investigated, coaching with the main principles of CDA, which are the descriptions of the text, discourse as discursive practice, and discourse as social-practice. At the second level, in order to determine how King Abdullah II frames the core issue in his speeches, four persuasive strategies of political discourse were employed. These strategies are creativity, reference, circumlocution, and intertextuality. They found that King Abdullah used these strategies which are actually power in his discourse, in terms of employing them to deliver his messages. He uses the creative expressions to show the reality as it is, i.e. the bad image of the current state of affair and the potential good image of the future, which is the use of power in his discourse.

Negma (2015) studied literary discourse as a context for power to be resisted and challenged from a new perspective: the conflictual strategies of power. It has been shown that discourse is not only a context for power to be enacted, exercised and maintained but also a context for power to be questioned, challenged, contested and resisted. He took the discursive practices into consideration. Whereas in the present study Discourse which is selected is political as well as textual, discursive and social practices of $3 \mathrm{D}$ model is taken into consideration.

In another study Iqbal (2015) studies the pre and post-election speeches of political leaders in Pakistan. The purpose of the study was to analyze the rhetorical devices: Repetition, modality, and positive self- presentation, negative other presentation, ethnicity and figurative speech (metaphor, simile and personification) and power in discourse in pre and post-election speeches of relatively popular political leaders of Pakistan. The paper investigated the linguistic implications of these rhetorical devices. A qualitative content analysis of data (collected from a sample of fifteen prominent politicians) was undertaken to address the underlying research questions. The findings uncover that the politicians exploit persuasive devices to foster consent, demonstrate ideologies and assert power. The use of rhetorical devices seemed more or less context dependent.

\section{Methodology}

In order to find out power within the discourse and power behind the discourse of the two selected speakers of Dharna 2014, the researcher has done qualitative research. The researcher delimited only the data concerning the speeches of Imran Khan's dharna speeches delivered in 2014 which are available on the internet i.e. Google, YouTube and Daily motion, because all the speeches of Dharna 2014 are not available on internet. Data were analyzed by using Flairclough's 3D model and framework which consisted of three aspects including text, socio-cultural and discursive practices in a society. This framework provides the base for analyzing variables like social, cultural and ideology in Imran Khan Dharna speech.

\section{Results}

Data analysis included the analysis at three levels: textual, discursive and societal levels.

\section{Textual Analysis}

In textual analysis, cohesion, modality, vocabulary, transitivity, and pronoun are focused.

\section{Cohesion}

In Cohesion, the use of conjunction and references is analyzed. References include epiphoric, anaphoric and cataphroic. Epiphoric references are replication of the last part of the phrase and anaphoric is the repetition of the starting part of the phrase whereas cataphoric is the word which takes reference from the previous words. 
Table No. 1 Abstract taken from Imran khan speech for the analysis of cohesion

\begin{tabular}{|c|c|c|}
\hline Sr. No & Extract in Urdu & English Translation \\
\hline 1. & $\begin{array}{l}\text { inke pichay a raha he, inke pichey kon a raha he, inka } \\
\text { ihtesab krney ke liye eik bra khoofnak insan a raha hey. }\end{array}$ & $\begin{array}{l}\text { He is coming for them, who is coming } \\
\text { to them, a horrible person is coming for } \\
\text { their accountability. }\end{array}$ \\
\hline 2. & $\begin{array}{l}\text { Mehengai bi Imran khan ki wajha say hay, dako bhi } \\
\text { Imran khan ki wajha say hay, gurbat bhi Imran khan ki } \\
\text { wajha say ha, kabza b Imran khan ki wajha say hain. }\end{array}$ & $\begin{array}{l}\text { Rise in prices is also due to Imran } \\
\text { khan; looters are also due to Imran } \\
\text { khan; poverty is also due to Imran } \\
\text { khan; illegal control is also due to } \\
\text { Imran khan. }\end{array}$ \\
\hline
\end{tabular}

As shown in Table.1, the speaker has used epiphoric reference in order to combine the clauses. He repeated the last part of the clause 'coming for them' in order to lay stress on his stance as well as generate curiosity amongst the audience and to threaten the opposition leaders as he called himself a 'horrible' person to create a terrifying image of his personality and show dominance over the rulers. The speaker has displayed explicit power play by 'coming for them'.

However, second example given in Table 1 shows the use of epiphoric reference 'due to Imran Khan' used by the speaker in order to add a series of points used by the opposition against him. The speaker here is giving the impression of wrongness of the opposition parties as all the problems which people of the country facing are because of Imran khan.

As shown in the Table 2, there is no use of conjunction in order to maintain the flow of speech. The speaker named all the politicians who said that there was election rigging to inculcate the righteousness of his point of election rigging. The phrase 'there was election rigging' is used as an epiphoric reference in order to stress the main point of the topic of the speech, which was election rigging in case of this extract. This also shows the implicit display of power by the speaker as he used name of other politicians to show the righteousness.

\section{Table No. 2 Abstract taken from Imran khan speech for the analysis of cohesion}

\begin{tabular}{|c|c|c|}
\hline Sr. No & Extract in Urdu & English Translation \\
\hline 1. & $\begin{array}{l}\text { 'Humney mil k koshish ki, assembly ka joint section } \\
\text { bana liya, Asif Zardari bhi kehta hey } k \text { dhandli hoi, } \\
\text { Nawaz Shareef ki party bhi kahti hay dhandli hoi, } \\
\text { Molana Fazal-ur-Rehman bhi kehta hay } k \text { dhandli } \\
\text { hoi, Asfandyar bhi kahta hay } k \text { dhandli hoi, } \\
\text { Balochistan ki party bhi kahti ha dhandli hoi. }\end{array}$ & $\begin{array}{l}\text { We tried together and made a joint section, } \\
\text { Asif Ali Zardari also says there was election } \\
\text { rigging, Nawaz Shareef's party also says there } \\
\text { was election rigging, Molana Fazal-ur- } \\
\text { Rehman also says there was election rigging, } \\
\text { Asfandyar also says there was election } \\
\text { rigging, Balochistan's party also says there } \\
\text { was election rigging. }\end{array}$ \\
\hline 2. & $\begin{array}{l}\text { Tu hum phalay adalat main jaein gay aur pochain } \\
\text { gay } k \text { hamara paisa apni kurci bachanay } k \text { liay } \\
\text { kiyun ker rahay hain. }\end{array}$ & $\begin{array}{l}\text { Firstly, we will go to the judiciary and ask } \\
\text { them why they are using our money to retain } \\
\text { their political status. }\end{array}$ \\
\hline
\end{tabular}

The second example in the Table 2, however, shows the explicit power play of the speaker as he says that they will go to the judiciary, and by using conjunction 'and' he adds information to his previous clause and makes clear his agenda that why they will go to the court because they will ask the rulers why they are using our money to save their political status. The speaker is inculcating his plans in the minds of the audience.

Table No. 3 Abstract taken from Imran khan speech for the analysis of cohesion

\begin{tabular}{|c|c|c|}
\hline Sr. No & Extract in Urdu & English Translation \\
\hline 1. & $\begin{array}{l}\text { Ya jo metro bani ha, Lebnon mein } 3 \text { million } \\
\text { dollars kum pey bani ha, Turkey main } 4.5 \\
\text { million dollars kum pey bani hay, Lahore main } \\
11 \text { million dollars kum pey bani hey, aur } \\
\text { Islamabad wali } 20 \text { million dollars pey ban rahi } \\
\text { hay. }\end{array}$ & $\begin{array}{l}\text { As far as Metro is concerned, Lebanon made it } \\
\text { in } 3 \text { million dollars, Turkey made it in } 4.5 \\
\text { million dollars, while Lahore made it in } 11 \\
\text { million dollar and the one in Islamabad is } \\
\text { taking } 20 \text { million dollars to construct. }\end{array}$ \\
\hline 2. & $\begin{array}{l}\text { Jo insan dhandli ker } k \text { assembly main ata hay, } \\
\text { kiyya wo assembly ma aa key imaandaar ho jata } \\
\text { ha, jo aadmi apna zameer baich key corruption } \\
\text { ker key ata hay wo imaandaar ho jata hay. }\end{array}$ & $\begin{array}{l}\text { He who does rigging and joins assembly does } \\
\text { he become honest? The person who does } \\
\text { corruption, going against his conscience, does } \\
\text { he become honest? }\end{array}$ \\
\hline
\end{tabular}


The first example in Table 3 shows that the speaker gives references of the other counties like Lebanon and Turkey to make his point strong and portray the negative image of the rulers that they are using more money for the Metro project as compared to other countries. He has not used any conjunction in this extract in order to maintain the flow of his speech and add more points to his main point. Here, power is working behind the discourse of the speaker as the speaker is using mechanism of universal acceptance by referring to other countries of the world.

The second example in Table 3 shows the use of epiphoric reference by the speaker to stress his question i.e. 'does he become honest'. He is implicitly displaying power play by referring to the corrupt leaders of the ruling party and is asking question from the audience exposing the wrong actions so as to convince the audience that his point is valid. Thus, the audience is manipulated by using mechanism of communication.

\section{Pronoun}

The speaker used pronouns like 'I', 'We', 'Our', 'Them', 'Their', 'He' for referring to himself and others. For example,

'Ma wahan giya,ma nay zakhmi bachon say baat ki, main es nateejay pay pohncha'

I went there, I talked to the injured children, I concluded this.

Here, speaker has used Pronoun 'I' to narrow down the focus of the audience to himself and telling people what he did. The phrase 'I concluded this' shows the powerful nature of the speaker that he knows his status and is using explicit power play to tell his point of view. In another example,

'Inka waqt khtam hu geay ha, in logon nay jo Pakistan ko lotna thaw lot lia ha'.

Their time is over, they have looted Pakistan as much as they could.

Here, the speaker used the pronoun 'Their' and 'they' for the rulers in order to make direct link of the audience to his point that the ruler's time is over. He explicitly displayed power by portraying negative image of the rulers by saying 'they have looted Pakistan as much as they could'. Again, the speaker used the pronoun ' $I$ ' in the following sentence,

'Itni dair marzi lag jai ma ap key liay kahrra hon'

I am standing with you no matter how long it takes.

He leads the audience focus on him and he gives positive image of himself that he is standing with the audience forever. Here, ' $\mathrm{I}$ ' is used to win the hearts of the audience. In the following example, the speaker presents himself one with the audience to win their acceptance by using the pronoun 'we'.

'Hum kia agla kadam uthnay lagay hain'

What is the next step we are going to take.

Here, 'We' shows the speaker and the audience. In the next example, the speaker has used pronoun 'I' again.

'Ma nay kaha chaar halky khol do, ager un main dhandli nahin hoi tu hum election main jaein gay'

I asked them to open four constituencies. If no election rigging is proved, we will accept the election.

In the above sentence, the use of 'I' and 'we' reflects the explicit display of power in his discourse by first telling what he said to the rulers and then he used 'We' to show the audience and himself as one who will accept elections if it is proved that there was no rigging. He again used 'they' for the rulers and tells the audience that the money they have earned from metro, they will buy people with it.

'Inhon nay jo paisa kamaya hay metro say ab us say loog khareedain gay'

They will use money earned from metro to influence people.

The speaker again used pronoun 'We' to show himself and the audience as one entity:

'Jab hum yahan pochay, tu hm nay un ko kaha, election main dhandli hoi ha'

The time we arrived here, we told them that there was vote rigging.

The speaker used 'My' in the following sentence:

'Mere pakistanio, ap tyyar hain es key liay'

My Pakistani people, are you ready for this.

The word 'My' is used to show the audience as his people or his Pakistani people in order to show himself as the leader of these people. In another example, he said:

'Main nay kabhi nahin socha thaw key Allah meri qoam ko aisa jagaye ga jis terha us nay jagaya hay'

I never thought that Allah will wake my nation up like this. 
Here, 'My' pronoun is used by the speaker which is used by the speaker to gain the acceptance of the audience.

\section{Modality}

Modality is "Focus on the speaker's degree of affinity with or affiliation to her or his statement" (Jørgensen et al., 2002: 83), i.e. the degree to which the speaker commits to a statement. On type of modality is truth, i.e. the speaker commits him or herself completely to the statement. Opposite of the truth is hedges, which is when the speaker expresses low affinity to the statement, e.g. by using words such as 'a bit' (Jørgensen et al., 2002: 84).

Imran khan has used modal verb 'will' many times in his speeches to show the degree of affinity. Sometimes, he showed subjective degree of affinity and sometimes objective degree of affinity to display explicit and implicit power play in his discourse (Fairclough, 1992). Consider the following example:

'Es ko aik azeem mulk banay ga'

Make it a prosperous country.

The speaker in the above example showed the implicit power play with objective degree of affinity as the subject is not specified. Consider another example:

'Main ap say wada kerta hun, meri baat sun lu jab tak main zinda hun mein idher say janay nahin wala jab tak Nawaz Sharref isteefa nahin day deita'

Listen to me, I promise you that I am not going anywhere till my last breath unless Nawaz Sharif will not resign.

In this example, the pronoun 'I' shows subjectivity and the modal verb 'will' shows the degree of affinity which is very strong. The statement shows the commitment of the speaker that he is fully committed to do whatever he is saying. Ultimately, the speaker wins the audience's acceptance using mechanism of communication. In the next example, the speaker again used subjective degree of affinity through the pronoun 'I' saying that if he has to stay there for a year he will stay there.

'Mujha aik saal bhi yahan rehna para main app key liey rahon ga'

If I have to stay there for a year, I will stay here for you.

In the following example, the pronoun 'I' is used with model verb 'will' to make a commitment to his people that he 'will' not go before freeing the country form Nawaz shareef.

'Mein nay es mulk ko Nawaz shareef say azad kiye baghair nahin joun ga'

I am not going unless freeing this country from Nawaz Shareef.

Commitment to the people is also shown through the verb 'will' in the following example:

'Pehlay tu InshAllah, hum adalt main jain gay'

Firstly we will go to the court Insha Allah.

The pronoun 'we' reflects explicit power display of the speaker.

The speaker once again used 'will' to show the consequences of the being quiet against the rulers in order in invoke anger in the audience.

'Ap ka bacha inn kay bachon ki gulami krey ga'

Your children will do slavery of their children.

Here 'will' is used in a negative way in order to show the consequence of being remaining quiet. In another example, Imran khan makes a very strong degree of affinity in a subjective manner by using 'will' that he will reach Lahore on $4^{\text {th }}$ and shut down Lahore. He will go to Faisalabad on $8^{\text {th }}$ and shut down Faisalabad. He will go to Karachi on $12^{\text {th }}$ and shut down Karachi. He will shut down the whole Pakistan on $16^{\text {th }}$. This shows his full commitment towards his statement and display explicit power play in his discourse.

'Chaar tareekh ko Lahore pohonchon ga aur Lahore band karoon ga, $8^{\text {th }}$ tareekh ko main Faislabad band kroon ga, 12 ko main Karachi jaon ga aur Karachi band karoon ga, 16 ko ma sara Pakistan bund karoon ga'

On $4^{\text {th }}$ I will reach Lahore and shut down Lahore, on $8^{\text {th }}$ I will shut down Faisalabad, on $12^{\text {th }}$ I will move to Karachi and will shut down Karachi, on $16^{\text {th }} I$ will shut down whole Pakistan.

In the next example he explicitly displayed power by saying:

'Ap ka mokabala karoon ga aur tabdeli lay key deikhaoun ga'

I will fight you and bring the change.

Here 'will' is used in the sense of something the speaker will do in the future and the use of pronoun 'I' shows his strong degree of affinity to his statement by explicitly displaying power. 


\section{Vocabulary}

Imran khan used words like 'Culprit' for the rulers to give their negative image to the audience in the following sentence:

'Is liay saray mujrim akhathay ho gaye hain'

That is why all the culprits are united.

He also used word 'fraud' in the following sentence:

'2013 ka election ma Pakistan ma sab sa bara fraud hoa'

Elections held in 2013 were the biggest fraud.

He used this word to show the unfairness of the rulers by using power in his discourse with 'fraud' in order to gain the acceptance of the audience on his side by mechanism of communication. He used 'Unemployed' for the 'poor people' in the following sentence and compared them with the leaders and called them 'looters' to show their unfairness to the people of the country by explicitly displaying power.

'Ak berozgar hay wo churi kerta hay,10 rupay chori kerta hay hum kehtay hain chor hay ,Mian Saab ap ney erboun rupey chori kiye hain ap ko main dako na kahon tu kia kahon'.

There is one who is unemployed and used to steal the things, steal ten rupees and we said that he is a thief, Mian saheb, you have stolen billions so what else I need to say you except a thief.

He used word 'etiquettes' on behalf of the opposition leaders and explains the reason behind his lack of etiquettes for them.

'Yay kahtay hain main tameez say baat nahin kerta'.

He said that I have no etiquettes to talk.

He calls the rulers 'murderers' to show the impossibility of fair investigation under them.

Model town main Jo qattal hoa, 100 logon ko golian lagin, Shahbaz Shareef kay neechay gair janibdaar tafteesh kaisay ho sakti hay.

What happened in Model town, 100 people get bullets, how's that possible that there would be a fair investigation under Shahbaz shareef'.

He used words like:

'Mazloom, kamzor, mazdoor. khawateen, aqliyatein'.

Powerless, laborers, women, minorities.

He used these words to show his mindset that he is with these poor people as they only have one right i.e. right to vote otherwise they are very powerless people. He then invokes the anger in the audience by saying that,

'Ap ka bacha ein key bachon ki gulami karin gay'

your child will do slavery of them.

Imran khan also used the words 'awake' in the following sentence for the audience which shows that the speaker appreciates the audience for being out with him for justice.

'Ma nay kabhi nahin socha thaw $k$ Allah meri qoom ko aisay jagay ga'

I have never thought of my people that Allah will awake them in this way.

This also reflects explicit display of power. He also used words like 'strong' in the following sentence for himself to show to the rulers that he has the ability to fight more and show his enthusiasm.

Aik tu inhon nay mujhay aur ziyada muzboot ker diya hay. jaisay bunday ka muscles mazbot hota hay.

They have made me even stronger. Just like a man who has strong muscles.

He used words like 'feudal lords' or 'Badsha salamat' for the rulers to show them as the unjust rulers who are not working for the benefits of the people. He also used words like 'scared' for the one of the ruler like Asif Ali Zardari to explicitly show the display of power.

'Asif Zardari dara hua hay'

Transitivity

Asif Zardari is scared.

Transitivity is "How events and processes are connected (or not connected) with subjects and object" (Jørgensen et al. 2002: 83), with this focus it is possible to determine the agent of the action, or if there is an agent at all. Omitting an agent can remove responsibility for an action, presenting the action as something socially accepted (Jørgensen et al. 2002: 83). 
Table No. 4. Abstract taken from Imran khan speech for the analysis of Transitivity

\begin{tabular}{|c|c|c|}
\hline Sr. No & Extracts in Urdu & English Translation \\
\hline 1. & $\begin{array}{l}\text { "Aaj Nawaz Shareef ney Molana Fazal-ur- Rehman ki } \\
\text { duty lagai thi key KPK ko bund karo" }\end{array}$ & 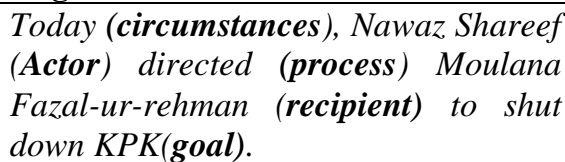 \\
\hline 2. & $\begin{array}{l}\text { "Ishaaq Daar kehta hey jab sey dharna shoro howa } \\
\text { moashi halaat behter ho gaey molk key" }\end{array}$ & $\begin{array}{l}\text { Ishaq Dar (actor) says that dharna has } \\
\text { improved (process) the economic } \\
\text { situation (goal) of the country } \\
\text { (recipient). }\end{array}$ \\
\hline 3. & $\begin{array}{l}\text { "BBC ney aik film bhi banayi thi key keisy Nawaz } \\
\text { Shareef paisa chori kerta ha" }\end{array}$ & $\begin{array}{l}\text { BBC (actor) has made a film(process) } \\
\text { on how Nawaz Shareef (recipient) } \\
\text { steals money illegally (goal). }\end{array}$ \\
\hline
\end{tabular}

Example 1 in Table No. 4 shows that the then ruler Nawaz Shareef assigned the task of shutting down KPK to Molana Fazal-ur-Rehman. The dominant role of the rulers is evident form the example in which they have given orders to shut down KPK in order to show their dominance. This also shows the explicit display of power of the rulers.

Example 2 in Table 4 shows that one member of the ruling party is appreciating the sit-in as in his view it is helping the country in boosting the economy. This shows that the opposition is appreciating the sit-in by the speaker which shows the implicit display of power by the speaker.

Example 3 in Table No. 4 shows the negative image of Nawaz Shareef by the speaker as he has mentioned the source which has made a film on Nawaz Shareef regarding his corruption. Thus, the speaker has displayed explicit power play through this sentence.

Table No. 5 Abstract taken from Imran khan speech for the analysis of transitivity

\begin{tabular}{lll}
\hline Sr. No & Extracts in Urdu & English Translation \\
\hline 1. & 'Asif Ali Zardari dara hua hay k kis terha main pohanch raha & $\begin{array}{l}\text { Asif Ali Zardari (Actor) is scared } \\
\text { that how (process) I (actor) would } \\
\text { hun Larkana'. }\end{array}$ \\
reach Larkana (goal). & $\begin{array}{l}\text { Nawaz shareef (Actor) has } \\
\text { destroyed (process) our (recipient) } \\
\text { country (goal). }\end{array}$
\end{tabular}

Example 1in Table 5 shows the power of the speaker through which he has scared Asif Ali Zardari and Zardari is surprised as to how the speaker will reach Larkana. It shows the explicit display of power by the speaker.

Example 2 in Table 5 shows the manipulative nature of the language. The speaker is using words to manipulate the audience by saying that Nawaz Shareef he has destroyed their country. He used implicit display of his power by showing negative image of Nawaz Shareef.

\section{Discursive Level}

Interdiscursitivity and intertextuality are used to analyze the data under this level.

At discursive level, the notion of intertextuality offers a perspective of both reading and writing texts as a way of looking at a text's interactions with prior texts, writers, readers, and conventions. Thibault (1994:1751) explains this perspective stating: "All texts, spoken and written, are constructed and have the meanings which text-users assign to them in and through their relations with other texts in some social formation". Fairclough (1992: 84) defines it as "The property texts have of being full of snatches of other texts, which may be explicitly demarcated or merged in, and which the text may assimilate, contradict, ironically echo, and so forth".

Table No. 6 Abstract taken from Imran khan speech for the analysis of inter-discursitivity

\begin{tabular}{lll}
\hline Sr. No & Extract In Urdu & English Translation \\
\hline 1. & 'Allah ka qanoon ha saza aur jaza ka. Jo jurm & Allah has created the law of punishment and \\
& karey us ko saza do aur jo acha kaam kare us & reward, he who commits a crime punish him and \\
& ko jaza do, us ko faida ho'. & he who does a good deed, reward him.
\end{tabular}

As shown in the Table 6, Imran khan has brought the Islamic discourse into the political discourse. He gives logical reasoning that due to the rule of God mentioned in the extract, India is better than us because they put all the sinners in jails, whereas in Pakistan, they are put into the assemblies. This extract shows relatively innovative type of a discourse as the speaker is using 
discourse of Islam to support his argument. Another reason of using Islamic discourse is that majority of the audience of Dharna were Muslims which gave the speaker a chance to win their hearts.

Table No. 7 Abstract taken from Imran khan speech for the analysis of interdiscursitivity

\begin{tabular}{lll}
\hline Sr. No & Extract in Urdu & English Translation \\
\hline 1. & '...aap nay Zardari sey mil key 2013 kay election ka match & $\begin{array}{l}\text { You together with Zardari fixed the } \\
\text { match of elections 2013. They did it } \\
\text { together. }\end{array}$ \\
\hline
\end{tabular}

As shown in the Table 7, the speaker has brought the discourse of sports in the political discourse by using narrative mode to tell the audience how Nawaz Shareef and Asif Ali Zardari did rigging in elections of 2013. The speaker, being a sportsman was able to use the expression 'match fixing' in his speech.

Table No. 8 Abstract taken from Imran khan speech for the analysis of interdiscursitivity

\begin{tabular}{lll}
\hline Sr. Nu & Extract in Urdu & English Translation \\
\hline 1. & To merey pakistanio yeh jo mein aap ko bata raha hon & $\begin{array}{l}\text { So, my countrymen, whatever I am } \\
\text { telling you, note it down. }\end{array}$ \\
\hline
\end{tabular}

As shown in the Table 8, the speaker has used mode of exposition to set his agenda. He first sets the ground by saying that the problem with Pakistan is the justice system of Pakistan which is different for poor and rich. He then shows his dominance by saying 'but they are scared of me' in order to reflect negative light on the rulers. Then, he brings sports discourse into his political speech and explains how sports help a person to learn how to fight. The tenor of speaker and the rulers is that of competitors and the tenor of speaker and the audience is that of supporters of each other.

\section{Intertextuality}

Fairclough (1992) defines intertextuality as an instance of mixing of genres, discourses and styles in a text. Genres are ways of acting (interacting) i.e., speech, interview and lecture are different genres and they demand specific ways of acting and interacting with discourse users.

\section{Table No. 9Abstract taken from Imran khan speech for the analysis of intertextuality}

\begin{tabular}{lll}
\hline Sr. No & Extract in Urdu & English Translation \\
\hline 1. & "Soviet Union ka bohat bara dictator tha Stalen, us ney & Stalen was a renowned dictator in \\
& kaha ye nahin ferk parta kay vote kon daal raha hey, is sey & Soviet Union. He once said, who \\
koiferk nahin parta, sirfye dekho key vote ginta kon hay." & $\begin{array}{l}\text { cast a vote doesn't matter, but the } \\
\text { one who counts it does. }\end{array}$ \\
\hline
\end{tabular}

As shown in Table 9, the speaker has brought text from text of one of the leaders of Soviet Union. This text is brought into the political text by the speaker when he explains that they only have one thing against the powerful people and that is vote. If there right to vote is taken from them by rigging election, then these poor people would have nothing against the powerful people. Thus, he took text of Stalin to support his point. The speaker here as presupposed that there was rigging in the 2013 elections and he used this text as polemical sentence against the rulers in order to inculcate the negative image of the rulers in the minds of the audience. This presupposition is used to manipulate the minds of the audience against the rulers.

\section{Table No. 10 Abstract taken from Imran khan speech for the analysis of intertextuality}

\begin{tabular}{lll}
\hline Sr. No & Extract in Urdu & English Translation \\
\hline 1. & "akher mey aap Nawaz Shareef, aap kay paas jesa engarezi & $\begin{array}{l}\text { In the end, Nawaz Shareef, as said } \\
\text { mein kehtay hain, as a ball is in your court, tou faisla ker lo." } \\
\end{array}$ \\
& take a decision.
\end{tabular}

As shown in the Table 10, Imran khan has used an idiom from English language by saying 'jesa engareizi main khetay hain' (as used in English language). The rhetorical mode used in this text is descriptive, as the speaker is portraying a vivid image of the situation. The idiom 'ball is in your court' reflects a negative image of the rulers that whatever happens now is up to Nawaz Shareef and he has to make a decision.

Table No. 11 Abstract taken from Imran khan speech for the analysis of intertextuality

\begin{tabular}{lll}
\hline Sr. No & Extract in Urdu & English Translation \\
\hline 1. & 'BBC ney eik film bhi banayi thi key keisy Nawaz Shareef & $B B C$ filmed a documentary \\
paisa chori kerta hay. Yani ye finace minister jhoot bol raha exposing the money laundering of & Nawaz Shareef. Ishaq Dar is lying \\
& hay aur ye Nawaz Shareef mujrim hay'. & and Nawaz Sharif is culprit.
\end{tabular}


Table 11 shows that Imran khan brought the text of BBC channel by directly mentioning the name of the channel to emphasize the authenticity of the information, he is sharing. He presupposed that Nawaz shareef is corrupt and in order to support his point he mentions text of BBC which show 'how Nawaz Shareef takes out money illegally.' He has used polemical type of sentence to show the negative image of the rulers by using 'chori krta hian' 'they take money illegally', thus, portraying rulers as 'thieves'. The rhetorical mode used by the speaker is exposition, as he is giving important information on the topic by bringing the other text into his discourse.

Table No. 12 Abstract taken from Imran khan speech for the analysis of intertextuality

\begin{tabular}{lll}
\hline Sr. No & Extract in Urdu & English Translation \\
\hline 1. & 'Maulana Romi say kisi nay pocha thaw keh Moulana sab & Once Maulana Romi was asked \\
& qoam kese marti hey? Moulana saab ney kaha jab ye qoum how a nation dies. He replied when \\
& ache aur buray ki tameez khatam karti hey qoum mar jati & a nation fails to draw a line \\
hey' & between good and bad, it dies.
\end{tabular}

Table 12 the speaker refers to Romi who held that a nation dies when there remains no difference between good and bad in the society. Imran khan is using exposition mode of discourse to first explain the point of view of a well-known person, and then compares his society to his point of view in order to reflect negative light on the rulers. The text is brought into his political discourse and used the text due to ideational meaning.

Table No. 13 Abstract taken from Imran khan speech for the analysis of intertextuality

\begin{tabular}{lll}
\hline Sr. No & Extract in Urdu & English Translation \\
\hline 1. & 'Hazrat Abu Bakher (AS) nay apna kapray ki dukhan band & Once selected as Caliph, Hazrat \\
& ker di thi jab khalifa bana. Kiyun kay un ko pata thaw un ki & Abubakar closed his shop of \\
& dukan ka koi mokabala nahin ker skay ga' & clothes with a fear that no one will \\
& be able to compete him because of \\
& his rank.
\end{tabular}

As shown in Table 13, the speaker brings Islamic discourse into his political discourse by referring to Hazrat Abu Bakr (RA)'s act of closing his business on selection as Caliph. The text brought into is not clearly demarcated, rather, it is translated into the voice of the political discourse of the speaker. The speaker has only brought the text due to the ideational meaning which the text is conveying.

\section{Societal Level}

At Societal level, the order of discourse is to specify the relationship of the instances of social and discursive practice to the orders of discourse it draws upon.

Table No. 14 Abstract taken from Imran khan speech for the analysis of order of discourse

\begin{tabular}{lll}
\hline Sr. No & Extract in Urdu & English Translation \\
\hline 1. & 'Aaj Nawaz Shareef ap ne Molana Fazal-ur- & Today, Nawaz shareef directed Maulana \\
& Rehman ki duty lagai thi key KPK ko bund karo, & Fazul-ur-Rehman to shut down KPK and he \\
& aur us ney pori koshshish ki key merey KPK key & tried his best to stop my tigers from reaching \\
& tiger yahan na pohnch sakain. Ab Nawaz Shareef & here. Now Nawaz Shareef see how PTI will \\
& aao deekhna PTI kesi bund kerti hey Pakistan ko'. & shut down Pakistan. \\
\hline
\end{tabular}

As shown in Table 14, the speaker first mentioned the discourse generated by the government regarding shutting down of KPK, and then, the speaker used another discourse in which he mentions that Molana Fazul-ur-Rehman tried his best to stop the people from reaching there. At the end, Imran khan gives threats in his discourse to Nawaz Shareef and warns him to watch, how he and his party will shut down Pakistan. Thus, the order of discourse is the layers of discourse which the speaker used.

Table No. 15 Abstract taken from Imran khan speech for the analysis of order of discourse

\begin{tabular}{lll}
\hline Sr. No & Extract in Urdu & English Translation \\
\hline 1. & 'Model town mani 100 logon ko goliyan & Hundred people were hit by bullets in model town, \\
& lagin,17 log Shaheed huey.........ptv & 17 people embraced martyrdom, PTV the place \\
,mushraf, so rh atahw container ma' & $\begin{array}{l}\text { where nobody is hit, no one died, they switched off } \\
\text { their transmission. You know when General }\end{array}$ \\
& $\begin{array}{l}\text { Mushraff switched off PTV for two hours in 1999, } \\
\text { then they immediately aired the transmission. The }\end{array}$ \\
& first thing I asked here was nobody is allowed to go \\
& inside of any government building.
\end{tabular}


As shown in Table 15, the order of the discourse of the speaker is that first he mentioned the tragedy of model town. Then, he moved to the discourse in which he mentioned the details of PTV transmission that it was the place where nobody was hit, but they still switched off their transmission. After this, the speaker moved towards the next layer of discourse that is the details of Musharraf's era in which PTV's transmission was closed, but for two hours only. At the end, the speaker moved toward the last layer of his discourse that he allowed no one to go in any governmental building.

\section{Conclusion}

The study showed number of instances where display of power is shown by the speakers at textual, discursive and societal levels which is power within discourse. The use of Urdu language has decreased the distance between the speaker and the audience, which is comprehensible for most of the population of Pakistan. The key findings include that the speakers showed the use of pronoun 'I' in order to show his power and dominating status, the pronoun 'we' to gain the support of the audience and to win their hearts and reflect this as a power on the rulers. The speakers explained in detail the unjust rule of the government by using different linguistic tools like modal verbs, vocabulary, transitivity, inter discourse etc. The study also showed the display of power at the discursive and societal levels. The power of west and Islam is more dominant in the speeches of Imran Khan. Thus, it is concluded that the leader displayed power explicitly in his speeches. There are other approaches in CDA as proposed by VanDijk and Wodak which can also be applied to carry out qualitative nature of research.

\section{References}

Al-Haq, F. A. A., \& Al-Sleibi, N. M. (2015). A Critical Discourse Analysis of Three Speeches of King Abdullah II. US-China Foreign Language, 13(5), 317-332.

Bayram, F. (2010). Ideology and political discourse: a critical discourse analysis of Erdogan's political speech. Annual review of education, communication \& language sciences, 7 .

Chimbarange, A., Takavarasha, P., \& Kombe, F. (2013). A Critical Discourse Analysis of President Mugabe's 2002 Address to the World Summit on Sustainable Development. International Journal of Humanities and Social Science, 3(9), 227-288.

Fairclough, N. (1989). Language and Power. London: Longman.

Fairclough, N. (1992). Discourse and Social Change. Cambridge: Polity Press.

Fairclough, N. (2001a). Language and power ( $2^{\text {nd }}$ ed.). Harlow: Pearson Education.

Gadavanij, S. (2002). Discursive strategies for political survival: a critical discourse analysis of Thai no confidence debates (Doctoral dissertation, University of Leeds).

Iqbal, A. (2015). Discourse Analysis of Prominent Politicians' Public Speeches. Linguistics and Literature Review (LLR), 1(1), 1-18.

Jørgensen, M., \& Phillips, L. J. (2002). Critical discourse analysis. Discourse analysis as theory and method, 60-93.

Kendall, G. (2007). What is critical discourse analysis?. In Forum Qualitative Sozialforschung/ Forum: Qualitative Social Research (Vol. 8, No. 2).

Negma, M. S. (2015). Resisting power in discourse. Procedia-Social and Behavioral Sciences, 192, 284-289.

Richardson, I. M. (1989). Discourse structure and comprehension. System, 17(3), 339-345.

Taiwo, R. (2007). Language, Ideology and Power Relations in Nigerian Newspaper Headlines. Nebula, 4(1).

Thibault, P. J. (1994). Intertextuality. In R. E. Asher (Ed.), The Encyclopedia of language and linguistics, Vol. 4. Oxford: Pergamon Press.

Van Dijk, T. A. (1997). What is political discourse analysis? Belgian journal of linguistics, 11(1), 1152.

Van Dijk, T. A. (2001). Critical Discourse Analysis. The handbook of discourse analysis, 352.

Van Dijk, T. A. (2006). Ideology and Discourse Analysis. Journal of political ideologies, 11(2), 115140.

Van Dijk, T. A. (2009). Critical Discourse Studies: A socio-cognitive approach. Methods of critical discourse analysis, 2(1), 62-86.

Wodak, R. (2004). Critical discourse analysis. In C. Seale, G. Gobo, J. F. Gubrium, \& D. Silverman (Eds.), Qualitative research practice. (pp. 197-213). London: Sage. https://doi.org/10.4135/ 9781848608191.d17 